\title{
Poor zinc status is associated with increased risk of insulin resistance in Spanish children
}

\author{
R. M. Ortega ${ }^{1,2 *}$, E. Rodríguez-Rodríguez ${ }^{2,3}$, A. Aparicio ${ }^{1,2}$, A. I. Jiménez ${ }^{2,4}$, A. M. López-Sobaler ${ }^{1,2}$, \\ L. G. González-Rodríguez ${ }^{1,2}$ and P. Andrés ${ }^{2,3}$ \\ ${ }^{1}$ Departamento de Nutrición, Facultad de Farmacia, Universidad Complutense de Madrid, 28040 Madrid, Spain \\ ${ }^{2}$ UCM Research Group: 920030, Universidad Complutense de Madrid, 28040 Madrid, Spain \\ ${ }^{3}$ Sección Departamental de Química Analítica, Facultad de Farmacia, Universidad Complutense de Madrid, 28040 Madrid, \\ Spain \\ ${ }^{4}$ Hospital Infantil Universitario Niño Jesús, Avenida Menéndez Pelayo 65, 28009 Madrid, Spain
}

(Received 15 December 2010 - Revised 6 May 2011 - Accepted 6 May 2011 - First published online 22 July 2011)

\begin{abstract}
Zn plays a key role in the synthesis and action of insulin. The aim of the present work was to determine whether a poorer Zn status was associated with insulin resistance in a group of 357 Spanish schoolchildren. Zn intake was determined by using a $3 \mathrm{~d}$ food record (i.e. Sunday to Tuesday). The body weight, height and waist and hip circumferences of all subjects were recorded and fasting plasma glucose, insulin and $\mathrm{Zn}$ concentrations were determined. Insulin resistance was determined using the homoeostasis model assessment (HOMA) marker. Children (11.5\%) with Zn deficiency (serum $\mathrm{Zn}$ concentration $<10.7 \mu \mathrm{mol} / \mathrm{l}$ ) had higher HOMA values than those with a more satisfactory $\mathrm{Zn}$ status (1.73 (SD 0.93)) compared with 1.38 (SD 0.90; $P<0.05$ ). An inverse correlation was found between the HOMA value and the serum $\mathrm{Zn}$ concentration $(r-0 \cdot 149, P<0.05)$. The risk of having a greater insulin resistance value (HOMA greater than the 75 th percentile) increased with age (OR 1.438; $95 \%$ CI 1.021, 2.027) and BMI (OR 1.448; 95\% CI 1.294, 1.619) and decreased as Zn serum levels increased (OR 0.908; $95 \%$ CI 0.835, 0.987; P<0.001). Moreover, an inverse relationship was observed between HOMA values and $\mathrm{Zn}$ dietary density $(r-0 \cdot 122)$, and the $\mathrm{Zn}$ intakes of male children with a HOMA value of $>3 \cdot 16$ made a significantly smaller contribution to the coverage of those recommended (59.7 (SD 14.7) \%) than observed in children with lower HOMA values (73.6 (SD 18.2) \%; $P<0.05)$. Taking into account that $\mathrm{Zn}$ intake was below than that recommended in $89.4 \%$ of the children, it would appear that increasing the intake of $\mathrm{Zn}$ could improve the health and nutritional status of these children, and thus contribute to diminish problems of insulin resistance.
\end{abstract}

Key words: Zinc status: Zinc intake: Insulin resistance: Children

$\mathrm{Zn}$, an essential trace element and a component of many enzymes, is involved in the synthesis, storage and release of insulin $^{(1-3)}$. Specially, Zn plays a major role in the stabilisation of insulin hexamers and the pancreatic storage of the hormone $^{(4)}$ and is an efficient antioxidant ${ }^{(5)}$, while oxidative stress is considered to be a main component in the initiation and progression of insulin resistance (IR) and diabetes ${ }^{(6)}$.

Furthermore, $\mathrm{Zn}$ may have an indirect insulin-like effect, since genetic studies have identified the islet-restricted $\mathrm{Zn}$ transporter ZnT8 as a likely player in the control of insulin secretion $^{(7,8)}$. When the serum $\mathrm{Zn}$ concentration falls, there is a concomitant reduction in insulin secretion and peripheral insulin sensitivity ${ }^{(1-3)}$ that may increase the risk of glucose intolerance, diabetes mellitus and $\operatorname{IR}^{(2,3,8,9)}$.
IR is an important public health problem in children and adolescents $^{(10,11)}$. It can contribute to the onset of CVD and type 2 diabetes mellitus ${ }^{(2,9)}$; anything that could prevent IR would therefore be of great public health interest. Correcting situations of $\mathrm{Zn}$ deficiency can reduce the risk for type 2 diabetes $^{(9)}$ and some authors report IR or insulin sensitivity to be improved by $\mathrm{Zn}$ supplements ${ }^{(2,3,12,13)}$.

Specifically, insulin sensitivity was improved in non-diabetic obese women after a $\mathrm{Zn}$ supplementation for 4 weeks, while no changes were observed in the placebo group ${ }^{(12)}$. Kelishadi et $a l^{(13)}$ evaluated the effects of zinc sulphate $v$. placebo on markers of IR, oxidative stress and inflammation in a sample of obese prepubescent children. This randomised, placebocontrolled, crossover trial was conducted among sixty obese children who were randomly assigned to two groups: one

Abbreviations: HOMA, homoeostasis model assessment; IR, insulin resistance; RI, recommended intake.

*Corresponding author: Professor R. M. Ortega, fax +34 9139418 10, email rortega@farm.ucm.es 
received $20 \mathrm{mg}$ elemental $\mathrm{Zn}$ and the other received a placebo on a regular daily basis for 8 weeks. After a 4 -week washout period, the groups were crossed over. There was no significant carryover effect, and a significant decrease was documented for apoB:apoA-I ratio, oxidised LDL, leptin and malondialdehyde, and total and LDL-cholesterol after receiving $\mathrm{Zn}$ supplement, while there were no significant changes after receiving a placebo. Moreover, high-sensitivity C-reactive protein decreased and markers of IR improved significantly after receiving the supplement, while they increased or impaired after receiving the placebo. Also, the mean weight, BMI and BMI $Z$-score decreased significantly in the supplemented group, whereas these values increased after receiving the placebo. These results are particularly important in view of the adverse consequences of both childhood obesity and early changes in markers of oxidative stress and inflammation. The authors suggest the need for studies examining the clinical usefulness of $\mathrm{Zn}$ supplementation in childhood obesity.

Very few studies have examined the potential effects of micronutrients on IR, particularly with respect to the paediatric age group ${ }^{(2,7)}$. Therefore, the hypothesis of the present study is that poor $\mathrm{Zn}$ status affects appreciable percentage of Spanish children and is associated with increased risk of IR.

\section{Experimental methods}

The present study involved six primary schools in Madrid, Spain, randomly selected from a list of all such schools in the city.

\section{Subjects}

Sample recruitment. The study subjects were 357 schoolchildren aged between 8 and 13 years. The school principals were contacted by phone to arrange an interview. Permission was requested to meet with the parents of the children in the 8- to 13-year age group. Once permission was given, the parents were explained the details of the study and all questions were answered. Signed permission was then sought to include their children in the study. All the subjects took part voluntarily.

The exclusion criteria were:

(1) A lack of authorisation to take part or the non-acceptance of any of the conditions required for the study to proceed.

(2) Non-attendance on days when tests or interviews were performed.

(3) Having a pathology that might modify the results, that might alter food habits (and therefore nutrient intake) or that recommended non-inclusion.

This study was conducted according to the guidelines laid down in the Declaration of Helsinki and all procedures involving human subjects/patients were approved by the Human Research Review Committee of the Pharmacy Faculty, Complutense University of Madrid. Written informed consent was obtained from all the parents of the children.

\section{Methods}

\section{Anthropometric survey}

All measurements were carried out at the schools in the morning and by following the norms set out by the World Health Organization $^{(14)}$.

Body weight and height were determined using a digital electronic balance (range $0 \cdot 1-150 \mathrm{~kg}$, precision $100 \mathrm{~g}$; Seca Alpha, GmbH, Igni, France) and a Harpenden digital stadiometer (range $70-205 \mathrm{~cm}$, precision $1 \mathrm{~mm}$; Pfifter, Carlstadt, NJ, USA) respectively. For these measurements, subjects were barefoot and wore only underwear. Subject's BMI was calculated as weight $(\mathrm{kg}) /$ height $^{2}\left(\mathrm{~m}^{2}\right)$.

Overweight and obesity were defined according to BMIspecific percentiles for age and sex in the reference population. The cut-off for overweight was the 85th percentile and for obesity the 97th percentile ${ }^{(15,16)}$.

Waist and hip measurements were determined using a Holtain flexible metallic tape (range $0-150 \mathrm{~cm}$, precision $1 \mathrm{~mm}$; Holtain Limited, Crymych, Wales, UK). Measurements were carried out while the subject was standing relaxed and with the tape held snugly around the body, although not tight enough to compress the subcutaneous adipose tissue. The waist was measured midway between the inferior margin of the last rib and the crest of the ileum, in the horizontal plane. The hip circumference was measured in the horizontal plane of maximum circumference encircling the buttocks and the pubic symphysis. An assistant helped to hold the tape on the side of the subject's body opposite to the measurer. The mean of the three measurements was used for analysis. The waist:hip ratio was then calculated.

\section{Dietary survey}

A 'weighed food record' was kept for three consecutive days including a Sunday (from Sunday to Tuesday) ${ }^{(17)}$. Parents were instructed to record the weights if possible - and to record the household measurements (spoonfuls, cups, etc.) if not - of all the food consumed outside school by their children. On Monday and Tuesday of the aforementioned $3 \mathrm{~d}$, trained personnel visited the school canteen, recorded the foods in the menu and weighed the amounts of food served to each child plus those each left on the plate.

The energy and nutrient contents of the ingested foods were then calculated using food composition tables ${ }^{(18)}$. The values obtained were compared with those recommended ${ }^{(19)}$ to determine the adequacy of the diets. Special attention was paid to the intake of energy and Zn. Recommended intake (RI) of Zn used to estimate the percentage coverage of the RI was $10 \mathrm{mg} / \mathrm{d}$ for children under 10 years old, and $12 \mathrm{mg} / \mathrm{d}$ for girls and $15 \mathrm{mg} / \mathrm{d}$ for boys older than 10 years $^{(19)}$. DIAL software (Alce Ingeniería, Madrid, Spain) was used to process all the data ${ }^{(20)}$.

Theoretical energy expenditure was established by taking into account the body weight, age and physical activity of all the children, using equations proposed by the Institute of Medicine ${ }^{(21)}$.

To validate the results of the dietetic study, we compared energy intake to the theoretical energy expenditure. 
The percentage discrepancy between the energy expenditure and the sum of the measured and declared intakes was determined using the following formula:

\section{Theoretical energy expenditure - energy intake}

$\times 100 /$ theoretical energy expenditure.

A negative value indicates the component involving the declared energy intake to be greater than that of the theoretical energy expenditure (probable over-reporting), while a positive value indicates it to be lower than that of the theoretical energy expenditure (probable under-reporting) ${ }^{(22)}$.

The index of nutritional quality of $\mathrm{Zn}$ was calculated as follows:

Zn density (mg/MJ)/density recommended (mg/MJ).

\section{Physical activity}

The subjects' physical activity was examined by a questionnaire, registering the length of time spent sleeping, eating, playing sports, etc. An activity coefficient was established for each subject ${ }^{(23)}$.

\section{Biochemical survey}

Blood samples were drawn by venipuncture between 08.00 and 09.00 hours after $12 \mathrm{~h}$ of fasting. The adequacy of the fasting period was checked by nurses before blood was collected.

Fasting insulin was measured by immunochemiluminometric assay ${ }^{(24)}$ (Abbott Diagnostics, Madrid, Spain; $\mathrm{CV}=4.8 \%$ ). Plasma glucose was determined colorimetrically using the glucose oxidase-peroxidase method (Vitros GLU Slides, Rochester, NY, USA; CV $=2 \cdot 8 \%)^{(25)}$.

The homoeostasis model assessment (HOMA) value was used to reflect the degree of IR. This was estimated from the fasting plasma glucose and serum insulin concentrations using the following formula ${ }^{(26,27)}$ :

$$
\begin{aligned}
\text { HOMA }= & \text { fasting plasma glucose }(\mathrm{mmol} / \mathrm{l}) \\
& \times \text { fasting serum insulin }(\mathrm{mU} / \mathrm{l})) / 22 \cdot 5 .
\end{aligned}
$$

The HOMA cut-off point for the diagnosis of IR was taken as $3 \cdot 16^{(28)}$

For determination of $\mathrm{Zn}$, blood was collected in traceelement-controlled Vacutainer tubes (Becton Dickinson, Le Pont de Claix, France). Serum Zn concentrations were determined by flame atomic absorption spectrometry using a Perkin-Elmer 3100 apparatus (Norwalk, CT, USA; $\mathrm{CV}=4 \cdot 1 \%)^{(29)}$.

The cut-off level for moderate $\mathrm{Zn}$ deficiency was $10 \cdot 7$ $\mu \mathrm{mol} / 1^{(30,31)}$.

\section{Statistical analysis}

Descriptive data were expressed as means and standard deviations. The Student's $t$ test (or the Mann-Whitney test if the distribution of the results was not homogeneous) was used to compare means. The ANCOVA was used to adjust the $\mathrm{Zn}$ intake for under-reporting energy intake (percentage). The $\chi^{2}$ test was used to determine the significance of differences between proportions. Relationships between variables were quantified using multiple linear regressions controlling for potential confounders. Logistic regression analysis was used to identify risk or protection factors, expressing the OR and the 95\% CI. All calculations were performed using RSIGMA BABEL Software (Horus Hardward, Madrid, Spain). Significance was set at $P<0 \cdot 05$.

\section{Results}

Girls had a larger hip circumference, a higher mean serum insulin concentration, a higher mean HOMA value, a lower waist:hip ratio and a lower mean plasma glucose concentration than boys (Table 1).

Absolute $\mathrm{Zn}$ intake was lower in girls, but the contribution of their intake to the coverage of the RI was greater; the RI for $\mathrm{Zn}$ is lower in girls 10 years or older ( $72 \%$ of study subjects) (12 mg/d compared with $15 \mathrm{mg} / \mathrm{d}$ in boys) ${ }^{(19)}$ (Table 2 ). On the other hand, ANCOVA showed that $\mathrm{Zn}$ intake was still different between males $(9.8(\mathrm{sD} 2 \cdot 1) \mathrm{mg} / \mathrm{d})$ and females $(8.54$ (SD 1.8$) \mathrm{mg} / \mathrm{d} ; \quad P<0.001$; data adjusted for percentage of under-reporting).

Children were divided into those with a serum $\mathrm{Zn}$ concentration of $<10.7$ and $\geq 10.7 \mu \mathrm{mol} / 1$ (Table 3 ). No differences were observed between these two groups in terms of the sex ratio; thus, the results for boys and girls are shown together. No differences were observed in terms of any of the anthropometric or dietetic variables measured between the concentration of $<10.7$ and $\geq 10.7 \mu \mathrm{mol} / 1$ groups, although the insulin and HOMA levels were lower in the $\geq 10.7 \mu \mathrm{mol} / 1$ group (Table 3 ).

A positive correlation was found between the HOMA value and age $(r 0.237)$, body weight $(r 0.504)$, height $(r 0.343), \mathrm{BMI}$ ( $r$ 0.463), waist circumference $(r$ 0.510), hip circumference ( $r$ 0.478), the waist:hip ratio $(r 0 \cdot 180)$, serum insulin $(r 0.984)$ and glucose $(r 0 \cdot 162)$, and the under-reporting intake $(r 0 \cdot 231)$. Inverse relationships were observed between the HOMA value and the serum $\mathrm{Zn}$ concentration $(r-0 \cdot 149)$ and $\mathrm{Zn}$ dietary density ( $r-0 \cdot 122 ; P<0 \cdot 05$ in all cases).

Logistic regression showed the risk of IR (i.e. a HOMA value greater than the 75 th percentile) to increase with age (OR 1.438; 95\% CI 1.021, 2.027) and BMI (OR 1.448; 95\% CI $1.294,1.619)$ and to diminish with increase in serum $\mathrm{Zn}$ concentration (OR 0.908; 95\% CI 0.835, 0.987; $P<0.001$ ). Sex had no significant influence on this risk.

No correlation was found between $\mathrm{Zn}$ intake and the serum Zn concentration, although among boys with a HOMA value of $>3 \cdot 16$, the contribution of $\mathrm{Zn}$ intake to the coverage of the RI (59.7 (SD 14.7)\%) was significantly lower than in boys with lower HOMA values (73.6 (SD 18.2) \%; $P<0.05$ )

Taking all the children together, when the dietary density of Zn was $<$ p25 (0.87 mg/MJ), significantly higher HOMA values were observed than when the dietary density was higher $(1.73$ (SD 1.09) compared with 1.33 (SD 0.82); P<0.01). 
Table 1. Age, blood data and anthropometric results for the studied childrent (Mean values and standard deviations)

\begin{tabular}{|c|c|c|c|c|c|c|}
\hline & \multicolumn{2}{|c|}{ Total ( $n$ 357) } & \multicolumn{2}{|c|}{ Boys ( $n$ 170) } & \multicolumn{2}{|c|}{ Girls ( $n$ 187) } \\
\hline & Mean & SD & Mean & SD & Mean & SD \\
\hline Age (years) & $10 \cdot 7$ & 1.0 & $10 \cdot 7$ & $1 \cdot 0$ & $10 \cdot 8$ & 0.9 \\
\hline Weight (kg) & $40 \cdot 0$ & 9.9 & 39.4 & $9 \cdot 8$ & 40.55 & 9.98 \\
\hline Height $(\mathrm{cm})$ & 143.73 & 8.73 & 143.04 & 8.7 & $144 \cdot 37$ & $8 \cdot 70$ \\
\hline BMI $\left(\mathrm{kg} / \mathrm{m}^{2}\right)$ & $19 \cdot 16$ & 3.33 & 19.05 & 3.3 & 19.25 & 3.33 \\
\hline Waist (cm) & 66.78 & $9 \cdot 17$ & $67 \cdot 25$ & 9.96 & 66.35 & 8.39 \\
\hline Hip (cm) & 79.09 & 8.99 & 77.57 & $8 \cdot 77$ & $80 \cdot 47^{\star \star}$ & 8.99 \\
\hline Waist:hip ratio & 0.84 & 0.06 & 0.87 & 0.06 & $0.83^{\star \star *}$ & 0.06 \\
\hline Overweight (\%) & \multicolumn{2}{|c|}{$13 \cdot 4$} & \multicolumn{2}{|c|}{$11 \cdot 2$} & \multicolumn{2}{|c|}{$15 \cdot 5$} \\
\hline Obesity (\%) & \multicolumn{2}{|c|}{$16 \cdot 5$} & \multicolumn{2}{|c|}{$20 \cdot 0$} & \multicolumn{2}{|c|}{13.4} \\
\hline Insulin (mU/l) & $7 \cdot 19$ & $5 \cdot 70$ & $6 \cdot 31$ & 4.49 & $8.00^{\star \star \star}$ & $6 \cdot 52$ \\
\hline Glucose (mmol/l) & 4.59 & 0.43 & 4.64 & 0.43 & $4.54^{\star}$ & 0.42 \\
\hline HOMA & 1.42 & 0.91 & 1.31 & 0.96 & $1.53^{*}$ & 0.85 \\
\hline Serum Zn $(\mu \mathrm{mol} / \mathrm{l})$ & $15 \cdot 55$ & 3.57 & $15 \cdot 35$ & 3.37 & $15 \cdot 73$ & 3.74 \\
\hline$<10.7 \mu \mathrm{mol} / \mathrm{l}(\%)$ & \multicolumn{2}{|c|}{11.5} & \multicolumn{2}{|c|}{11.8} & \multicolumn{2}{|c|}{$11 \cdot 2$} \\
\hline
\end{tabular}

Mean values were significantly different between boys and girls: ${ }^{\star} P<0.05,{ }^{\star \star} P<0.01,{ }^{\star \star \star} P<0.001$.

$\dagger$ The Student's $t$ test (or the Mann-Whitney test if the distribution of results was not homogeneous) was used to compare variables between boys and girls. The $\chi^{2}$ test was used to determine the significance of differences between proportions.

\section{Discussion}

The present dietetic and anthropometric results are similar to those obtained in other studies ${ }^{(32-34)}$. The serum $\mathrm{Zn}$ concentrations and the percentage of subjects with deficient serum $\mathrm{Zn}$ concentrations are also similar to those previously reported $^{(35-37)}$.

The percentage of children with IR in the present study (6.5\%) agrees with that reported for schoolchildren and adolescents by other authors in other countries ${ }^{(38-40)}$. The girls had higher HOMA values than the boys (Table 1), which also agrees with that reported by other authors ${ }^{(40,41)}$, perhaps because of hormonal differences ${ }^{(42)}$.

Children with serum $\mathrm{Zn}$ deficiency (concentration of $<10.7 \mu \mathrm{mol} / \mathrm{l}$ ) had poorer glycaemia, insulin and HOMA results than the members of the $\geq 10 \cdot 7 \mu \mathrm{mol} / 1$ group (Table 3 ). In fact, an inverse correlation was observed between serum
$\mathrm{Zn}$ concentration and that of insulin $(r-0 \cdot 1793)$ and the HOMA value $(r-0.149 ; P<0.05$ in all cases).

The risk of suffering IR (defined as a HOMA value greater than the 75th percentile) increased with age and BMI but fell with increasing serum $\mathrm{Zn}$ concentration $(P<0.001)$. Thus, Zn would appear to protect against IR, while increasing BMI and age raise the risk of IR. This influence of $\mathrm{Zn}$ on the HOMA value has been reported in other studies ${ }^{(2,3,7,9)}$.

Some authors have suggested that supplementing with $\mathrm{Zn}$ might help to reduce the BMI in children ${ }^{(43)}$, and thus help reduce HOMA values. However, no such trend was observed in the present study; the children with better Zn status did not have a lower BMI than those deficient in Zn (Table 3).

As found in all previous studies ${ }^{(38,40,44)}$, overweight/obese children had higher HOMA values (1.96 (SD 1.01)) than those of normal weight $(1 \cdot 22$ (SD 0.78); $P<0 \cdot 001)$. However,

Table 2. Intake of energy and zinc in the studied schoolchildrent (Mean values and standard deviations)

\begin{tabular}{|c|c|c|c|c|c|c|}
\hline & \multicolumn{2}{|c|}{ Total (n 331) } & \multicolumn{2}{|c|}{ Boys ( $n$ 156) } & \multicolumn{2}{|c|}{ Girls ( $n$ 175) } \\
\hline & Mean & SD & Mean & SD & Mean & SD \\
\hline Energy intake $(\mathrm{kJ} / \mathrm{d})$ & 8769 & 1412 & 8904 & 1392 & 8649 & 1423 \\
\hline Under-reporting (kJ) & $67 \cdot 3$ & 1916 & 909.9 & 1900 & $-683 \cdot 8^{\star \star *}$ & 1594 \\
\hline Under-reporting (\%) & -1.55 & 21.38 & 7.73 & $18 \cdot 45$ & $-9 \cdot 82^{\star \star \star}$ & 20.44 \\
\hline Zn intake $(\mathrm{mg} / \mathrm{d})$ & $9 \cdot 1$ & $2 \cdot 0$ & 9.4 & $2 \cdot 1$ & $8 \cdot 9^{*}$ & 1.8 \\
\hline Zn density (mg/MJ) & 1.06 & 0.27 & 1.07 & 0.27 & 1.05 & 0.26 \\
\hline Coverage of $\mathrm{Rl}(\%)$ & 74.9 & $19 \cdot 2$ & 71.6 & $21 \cdot 2$ & $77 \cdot 9^{\star \star \star}$ & $16 \cdot 7$ \\
\hline $\mathrm{Zn}$ intakes $<\mathrm{RI}(\%)$ & \multicolumn{2}{|c|}{89.4} & \multicolumn{2}{|c|}{$91 \cdot 7$} & \multicolumn{2}{|c|}{87.4} \\
\hline INQ & 0.71 & 0.17 & 0.71 & 0.18 & 0.72 & 0.16 \\
\hline INQ $<1(\%)$ & \multicolumn{2}{|c|}{93.4} & \multicolumn{2}{|c|}{$92 \cdot 3$} & \multicolumn{2}{|c|}{$94 \cdot 3$} \\
\hline
\end{tabular}

$\mathrm{RI}$, recommended intake $(10 \mathrm{mg} / \mathrm{d}$ for children under 10 years old and $12 \mathrm{mg} / \mathrm{d}$ for girls and $15 \mathrm{mg} / \mathrm{d}$ for boys older than 10 years $\left.{ }^{(19)}\right)$; INQ, index of nutritional quality $(\mathrm{Zn}$ density $(\mathrm{mg} / \mathrm{MJ}) /$ density recommended $(\mathrm{mg} / \mathrm{MJ})$ ).

Mean values were significantly different between boys and girls: ${ }^{\star \star \star} P<0.001$.

† The Student's $t$ test (or the Mann-Whitney test if the distribution of results was not homogeneous) was used to compare variables between boys and girls. The $\chi^{2}$ test was used to determine the significance of differences between proportions. 
Table 3. Differences observed between children with a zinc deficiency and those with no such deficiency†

(Mean values and standard deviations)

\begin{tabular}{|c|c|c|c|c|}
\hline & \multicolumn{2}{|c|}{$\begin{array}{c}\text { Serum } \mathrm{Zn}<10.7 \\
\mu \mathrm{mol} / \mathrm{l}(n 41)\end{array}$} & \multicolumn{2}{|c|}{$\begin{array}{c}\text { Serum } Z n \geq 10 \cdot 7 \\
\mu \mathrm{mol} / /(n 316)\end{array}$} \\
\hline & Mean & SD & Mean & SD \\
\hline \multicolumn{5}{|l|}{$n$} \\
\hline Men & \multirow{2}{*}{\multicolumn{2}{|c|}{$\begin{array}{l}20 \\
21\end{array}$}} & \multicolumn{2}{|c|}{150} \\
\hline Women & & & \multicolumn{2}{|c|}{166} \\
\hline Age (years) & $10 \cdot 6$ & 1.1 & $10 \cdot 8$ & 0.9 \\
\hline Weight (kg) & 38.8 & 11.6 & $40 \cdot 2$ & $9 \cdot 6$ \\
\hline Height (cm) & $141 \cdot 88$ & $10 \cdot 83$ & $143 \cdot 98$ & 8.41 \\
\hline BMI $\left(\mathrm{kg} / \mathrm{m}^{2}\right)$ & 18.83 & 3.22 & $19 \cdot 20$ & 3.35 \\
\hline Waist (cm) & 66.06 & 8.84 & $66 \cdot 87$ & 9.22 \\
\hline Hip (cm) & 78.57 & $10 \cdot 67$ & $79 \cdot 16$ & 8.77 \\
\hline Waist:hip ratio & 0.84 & 0.04 & 0.85 & 0.06 \\
\hline Overweight (\%) & \multicolumn{2}{|c|}{19.5} & \multicolumn{2}{|c|}{$12 \cdot 7$} \\
\hline Obesity (\%) & \multicolumn{2}{|c|}{$14 \cdot 6$} & \multicolumn{2}{|c|}{$16 \cdot 8$} \\
\hline Insulin (mU/l) & 9.46 & 5.03 & $6 \cdot 81^{\star \star}$ & 5.73 \\
\hline Glucose $(\mathrm{mmol} / \mathrm{l})$ & $4 \cdot 16$ & 0.27 & $4.64^{\star \star \star}$ & 0.41 \\
\hline HOMA & 1.73 & 0.93 & $1.38^{*}$ & 0.90 \\
\hline HOMA > $3.16(\%)$ & \multicolumn{2}{|c|}{$13 \cdot 9$} & \multicolumn{2}{|c|}{4.7} \\
\hline Serum Zn $(\mu \mathrm{mol} / \mathrm{l})$ & \multicolumn{2}{|l|}{7.96} & \multicolumn{2}{|l|}{$16 \cdot 54^{\star \star \star}$} \\
\hline Energy intake (kJ/d) & 8829 & 1451 & $8281^{*}$ & $919 \cdot 7$ \\
\hline Under-reporting (kJ) & 7.98 & 1927 & $553 \cdot 3$ & 1775 \\
\hline Under-reporting (\%) & $-2 \cdot 22$ & 21.77 & 3.93 & $17 \cdot 23$ \\
\hline $\mathrm{Zn}$ intake $(\mathrm{mg} / \mathrm{d})$ & $9 \cdot 1$ & 1.6 & $9 \cdot 1$ & 2.0 \\
\hline Zn density (mg/MJ) & 1.08 & 0.25 & 1.06 & 0.27 \\
\hline Coverage of RI (\%) & $78 \cdot 1$ & $16 \cdot 8$ & 74.5 & $19 \cdot 4$ \\
\hline Zn intakes $<\mathrm{Rl}(\%)$ & \multicolumn{2}{|c|}{$91 \cdot 7$} & \multicolumn{2}{|c|}{$89 \cdot 2$} \\
\hline INQ & 0.77 & 0.16 & 0.71 & 0.17 \\
\hline $\mathrm{INQ}<1(\%)$ & \multicolumn{2}{|c|}{93.9} & \multicolumn{2}{|c|}{$94 \cdot 2$} \\
\hline
\end{tabular}

HOMA, homoeostatic model assessment; RI, recommended intake $(10 \mathrm{mg} / \mathrm{d}$ for children under 10 years old and $12 \mathrm{mg} / \mathrm{d}$ for girls and $15 \mathrm{mg} / \mathrm{d}$ for boys older than 10 years $\left.^{(19)}\right)$; INQ, index of nutritional quality $(\mathrm{Zn}$ density $(\mathrm{mg} / \mathrm{MJ}) /$ density recommended (mg/MJ)).

Mean values were significantly different between boys and girls: ${ }^{\star} P<0.05$, ${ }^{\star * \star} P<0.001$.

† The Student's $t$ test (or the Mann-Whitney test if the distribution of results was not homogeneous) was used to compare variables between boys and girls. The $\chi^{2}$ test was used to determine the significance of differences between proportions.

no perturbation of $\mathrm{Zn}$ metabolism or the very low plasma $\mathrm{Zn}$ concentrations that some authors associate with obesity ${ }^{(45)}$ were observed. In fact, in the present study, the overweight/ obese children had serum $\mathrm{Zn}$ concentrations similar to those of lighter children (15.2 (SD 3.6) $\mu \mathrm{mol} / \mathrm{l}$ compared with 15.7 (sD 3.5) $\mu \mathrm{mol} / \mathrm{l}$ ).

No correlation was found between $\mathrm{Zn}$ intake and serum $\mathrm{Zn}$ concentrations. This agrees with that reported by other authors, who indicate that homoeostatic mechanisms maintain the serum $\mathrm{Zn}$ concentration, with no notable change occurring when $\mathrm{Zn}$ intake is restricted ${ }^{(46,47)}$. However, this can be only applicable for moderate intake restrictions, which is observed in the present study and other similar studies from developed societies, since serum $\mathrm{Zn}$ definitely declines under severe restrictions ${ }^{(2,35,36)}$.

$\mathrm{Zn}$ intake did, however, influence the HOMA value. An inverse correlation was found between the HOMA value and the dietary density of $\mathrm{Zn}(r-0.122, P<0.05)$. In addition, in children with a dietary density of $\mathrm{Zn}$ less than the 25 th percentile, the HOMA values were significantly higher than in children with greater dietary densities. Further, boys with a HOMA value of $>3.16$ had $\mathrm{Zn}$ intakes that contributed less to the coverage of the RI than observed in those with more adequate HOMA values.

It would appear that $\mathrm{Zn}$ status plays a role in modulating the HOMA value and the risk of IR in children. Hashemipour et $a l^{(2)}$ earlier reported that, compared with children administered a placebo, those receiving $\mathrm{Zn}$ supplementation $(20 \mathrm{mg} / \mathrm{d})$ experienced significant and favourable changes in BMI, certain cardiometabolic risk factors and IR.

Some authors suggest that, given the increase in the proportion of children with IR and the metabolic syndrome, providing $\mathrm{Zn}$ supplementation or increasing the $\mathrm{Zn}$ intake through the diet might help control this emerging health problem ${ }^{(2,3,12)}$.

These studies support the results obtained in the present investigation, since we have found that children with serum Zn deficiency had poorer glycaemia, insulin and HOMA results than children with adequate serum $\mathrm{Zn}$. Also, we have found that there is an inverse correlation between serum $\mathrm{Zn}$ concentration and HOMA value $(r-0.149)$ and that the risk of having HOMA greater than the 75 th percentile increased with age and BMI, but fell with increasing serum $\mathrm{Zn}$ concentration $(P<0 \cdot 001)$. The results of this study indicate that the risk of having greater IR reduced as serum $\mathrm{Zn}$ levels increased, probably due to the fact that $\mathrm{Zn}$ status is not optimal and can be improved.

As reported in other studies, the children's diets provided marginal $\mathrm{Zn}$ amounts ${ }^{(45,48)}$; indeed, $89 \cdot 4 \%$ of the children in our study had $\mathrm{Zn}$ intakes below those recommended (Table 2).

The present study has several limitations. First, we used serum $\mathrm{Zn}$ as a $\mathrm{Zn}$ status indicator. Although its validity as a $\mathrm{Zn}$ status indicator can be questioned, it remains one of the best tools that we have for this purpose and is the parameter used in most studies ${ }^{(2,3,12,35,36)}$. Also, the interpretation of the association between serum $\mathrm{Zn}$ concentrations and the HOMA value is complex. The serum $\mathrm{Zn}$ concentration is sensitive to various factors that have not been determined ${ }^{(2)}$, and further studies are needed in this issue. In any case, we consider that improving the $\mathrm{Zn}$ status of children is desirable from a nutritional point of view, and might help fight against IR.

\section{Acknowledgements}

This study was supported by the project FISS (PI060318) and the 'Creation and Consolidation Program Research Group at the Complutense University of Madrid, Madrid' (ref. GR58/ 08; code 4120787). None of the authors had any personal or financial conflict of interest. R. M. O., A. M. L.-S., E. R.-R. and A. A. contributed to the study design and E. R.-R., A. A., A. I. J. and L. G. G. R. performed the data collection. R. M. O., A. M. L.-S., E. R.-R., A. A. and P. A. were involved in data analysis and the interpretation of results. R. M. O., A. A., A. I. J. and P. A. contributed to the writing of the manuscript.

\section{References}

1. Gómez-García A, Hernández-Salazar E, González-Ortiz M, et al. (2006) Effect of oral zinc administration on insulin sensitivity, leptin and androgens in obese males. Rev Med Chil 134, 279-284. 
2. Hashemipour M, Kelishadi R, Shapouri J, et al. (2009) Effect of zinc supplementation on insulin resistance and components of the metabolic syndrome in prepubertal obese children. Hormones (Athens) 8, 279-285.

3. Jansen J, Karges W \& Rink L (2009) Zinc and diabetes - clinical links and molecular mechanisms. J Nutr Biochem 20, 399-417.

4. Wiernsperger NF (2003) Oxidative stress as a therapeutic target in diabetes: revisiting the controversy. Diabetes Metab 29, 579-585.

5. Prasad AS (2008) Clinical, immunological, anti-inflammatory and antioxidant roles of zinc. Exp Gerontol 43, 370-377.

6. Kaneto H, Katakami N, Matsuhisa M, et al. (2010) Role of reactive oxygen species in the progression of type 2 diabetes and atherosclerosis. Mediators Inflamm 2010, 453892.

7. Wiernsperger NF \& Rapin JR (2010) Trace elements in glucometabolic disorders: an update. Diabetol Metab Syndr 2, 70.

8. Rutter GA (2010) Think zinc: new roles for zinc in the control of insulin secretion. Islets 2, 49-50.

9. Sun Q, van Dam RM, Willet WC, et al. (2009) Prospective study of zinc intake and risk of type 2 diabetes in women. Diabetes Care 32, 629-634.

10. Artz E \& Freemark M (2004) The pathogenesis of insulin resistance in children: metabolic complications and the roles of diet, exercise and pharmacotherapy in the prevention of type 2 diabetes. Pediatr Endocrinol Rev 1, 296-309.

11. Lee JM (2006) Insulin resistance in children and adolescents. Rev Endocr Metab Disord 7, 141-147.

12. Marreiro DN, Geloneze B, Tambascia MA, et al. (2006) Effect of zinc supplementation on serum leptin levels and insulin resistance of obese women. Biol Trace Elem Res 12, 109-118.

13. Kelishadi R, Hashemipour M, Adeli K, et al. (2010) Effect of zinc supplementation on markers of insulin resistance, oxidative stress, and inflammation among prepubescent children with metabolic syndrome. Metab Syndr Relat Disord 8, 505-510.

14. World Health Organization (1995) Physical Status: The Use and Interpretation of Anthropometry. Report of the WHO Expert Committee. WHO Technical Report Series no. 854. Geneva: WHO.

15. Hernández M, Castellet J, Narvaiza JL, et al. (1988) Curvas y tablas de crecimiento (Growth Charts and Tables). Instituto de Investigación sobre crecimiento y desarrollo. Faustino Orbegozo Eizaguirre. Madrid: Editorial Garsi.

16. Rolland-Cachera MF, Deheeger M \& Bellisle F (2001) Définition actuelle et évolution de la fréquence de l'obésité chez l'enfant (Current definition and evolution of the frequency of obesity in children). Cah Nutr Diét 36, 108-112.

17. Ortega RM, Requejo AM \& López-Sobaler AM (2006) Questionnaires for dietetic studies and the assessment of nutritional status. In Nutriguia. Manual of Clinical Nutrition in Primary Care, pp. 456-459 [AM Requejo and RM Ortega, editors]. Madrid: Ed. Complutense.

18. Ortega RM, López-Sobaler AM, Requejo AM, et al. (2010) Food composition tables. In Food Composition. A Basic Tool for Assessing Nutritional Status, pp. 15-81 [RM Ortega, AM López-Sobaler, AM Requejo and P Andrés, editors]. Madrid: Ed. Complutense.

19. Ortega RM, Requejo AM, Navia B, et al. (2010) Recommended daily intakes of energy and nutrients for the Spanish population. In Food Composition. A Basic Tool for Assessing Nutritional Status, pp. 82-84 [RM Ortega, AM López-Sobaler, AM Requejo and P Andrés, editors]. Madrid: Ed. Complutense.
20. Ortega RM, López-Sobaler AM, Andrés P, et al. DIAL software for assessing diets and food calculations, [RM Ortega, AM López-Sobaler, P Andrés, AM Requejo, A Aparicio and LM Molinero, editors]. Madrid: Alce Ingeniería, S.A. http://www.alceingenieria.net/nutricion.htm (Accessed 1 November 2010).

21. Food and Nutrition Board (FNB)/Institute of Medicine (IOM) (2005) Dietary Reference Intakes: Energy, Carbohidrate, Fiber, Fat, Fatty Acids, Cholesterol, Protein and Amino Acids. Washington, DC: Institute of Medicine of the National Academies Press. www.nap.edu.

22. Ortega RM, Requejo AM, Andrés P, et al. (1995) Relationship between diet composition and body mass index in a group of Spanish adolescents. Br J Nutr 74, 765-773.

23. Ortega RM, Requejo AM \& López-Sobaler AM (2006) Activity questionnaire. In Nutriguia. Manual of Clinical Nutrition in Primary Care, p. 468 [AM Requejo and RM Ortega, editors]. Madrid: Ed. Complutense.

24. El Kenz H \& Bergmann P (2004) Evaluation of immunochemiluminometric assays for the measurement of insulin and C-peptide using the ADVIA Centaur. Clin Lab 50, 171-174.

25. Neese JW, Duncan P, Bayse D, et al. (1976) Development and Evaluation of a Hexokinase/Glucose-6-phosphate Debydrogenase Procedure for use as a National Glucose Reference Method. Atlanta: Center for Disease Control, GA. DHEW publication no. (CDC) $77-8330$.

26. Albareda M, Rodriguez-Espinosa J, Murugo M, et al. (2000) Assessment of insulin sensitivity and beta-cell function from measurements in the fasting state and during an oral glucose tolerance test. Diabetologia 43, 1507-1511.

27. Tripathy D, Carlsson M, Almgren P, et al. (2000) Insulin secretion and insulin sensitivity in relation to glucose tolerance: lessons from the Botnia Study. Diabetes 49, 975-980.

28. Keskin M, Kurtoglu S, Kendirci M, et al. (2005) Homeostasis model assessment is more reliable than the fasting glucose/ insulin ratio and quantitative insulin sensitivity check index for assessing insulin resistance among obese children and adolescents. Pediatrics 115, 500-503.

29. Smith JC Jr, Butrimovitz GP \& Purdy WC (1979) Direct measurement of zinc in plasma by atomic absorption spectroscopy. Clin Chem 25, 1478-1491.

30. Pilch SM \& Senti FR (1984) Assessment of the Zinc Nutritional Status of the U.S. Population based on Data Collected in the Second National Health and Nutrition Examination Survey, 1976-1980. Bethesda, MD: Life Sciences Research Office, Federation of American Societies for Experimental Biology.

31. Wallach J (2007) Interpretation of diagnostic tests. In Normal Values, pp. 3-25 [J Wallach, editor]. Philadelphia, PA: Wolters Kluwer. Lippincott Williams \& Wilkins.

32. Ortega RM \& Aparicio A (2007) Problemas nutricionales actuales. Causas y consecuencias (Current nutritional problems. Causes and Consequences). In Nutrición y Alimentación en la promoción de la salud (Food and Nutrition in Health Promotion), pp. 8-20 [RM Ortega, AM Requejo and RM Martínez, editors]. Madrid: UIMP, UIMP Comunicación.

33. Rodríguez-Rodríguez E, Navia B, López-Sobaler AM, et al. (2010) Associations between abdominal fat and body mass index on vitamin D status in a group of Spanish schoolchildren. Eur J Clin Nutr 64, 461-467.

34. Serra Ll, Ribas L, Aranceta J, et al. (2003) Obesidad infantil y juvenil en España. Resultados del estudio enkid (1998-2000) (Childhood and adolescent obesity in Spain. Results of the enKid study (1998-2000)). Med Clin (BarC) 121, 725-732.

35. Hotz C, Peerson JM \& Brown KH (2003) Suggested lower cutoffs of serum zinc concentrations for assessing zinc status: reanalysis of the second National Health and Nutrition 
Examination Survey data (1976-1980). Am J Clin Nutr 78 756-764.

36. Brown KH, Peerson JM, Rivera J, et al. (2002) Effect of supplemental zinc on the growth and serum zinc concentrations of prepubertal children: a meta-analysis of randomized controlled trials. Am J Clin Nutr 75, 1062-1071.

37. Sayeg Porto MA, Oliveira HP, Cunha AJ, et al. (2000) Linear growth and zinc supplementation in children with short stature. J Pediatr Endocrinol Metab 13, 1121-1128.

38. Eisenmann JC, DuBose KD \& Donnelly JE (2007) Fatness, fitness, and insulin sensitivity among 7- to 9-year-old children. Obesity (Silver Spring) 15, 2135-2144.

39. Holst-Schumacher I, Nuñez-Rivas H, Monge-Rojas R, et al. (2008) Insulin resistance and impaired glucose tolerance in overweight and obese Costa Rican schoolchildren. Food Nutr Bull 29, 123-131.

40. Manios Y, Moschonis G, Kourlaba G, et al. (2008) Prevalence and independent predictors of insulin resistance in children from Crete, Greece: the Children Study. Diabet Med 25, $65-72$.

41. Hirschler V, Maccallini G, Karam C, et al. (2009) Are girls more insulin-resistant than boys? Clin Biochem $\mathbf{4 2}$, 1051-1056.

42. Moran A, Jacobs DR Jr, Steinberger J, et al. (2002) Association between the insulin resistance of puberty and the insulin-like growth factor-I/growth hormone axis. I Clin Endocrinol Metab 87, 4817-4820.

43. Lee K, Lee J, Bae WK, et al. (2009) Efficacy of low-calorie, partial meal replacement diet plans on weight and abdominal fat in obese subjects with metabolic syndrome: a double-blind, randomised controlled trial of two diet plans - one high in protein and one nutritionally balanced. Int J Clin Pract 63, 195-201.

44. Chiarelli F \& Marcovecchio ML (2008) Insulin resistance and obesity in childhood. Eur J Endocrinol 159, Suppl. 1, S67-S74.

45. Marreiro DN, Fisberg M \& Cozzolino SM (2004) Zinc nutritional status and its relationships with hyperinsulinemia in obese children and adolescents. Biol Trace Elem Res 100, 137-149.

46. Gibson RS, Hess SY, Hotz C, et al. (2008) Indicators of zinc status at the population level: a review of the evidence. $\mathrm{Br}$ J Nutr 99, Suppl. 3, S14-S23.

47. Food and Nutrition Board (FNB)/Institute of Medicine (IOM) (2001) Dietary Reference Intakes for Vitamin A, Vitamin K, Arsenic, Boron, Chromium, Copper, Iodine, Iron, Manganese, Molybdenum, Nickel, Silicon, Vanadium, and Zinc. Washington, DC: Institute of Medicine of the National Academies Press. www.nap.edu.

48. Hotz C (2007) Dietary indicators for assessing the adequacy of population zinc intakes. Food Nutr Bull 28, Suppl. 3, S430-S453. 